\title{
Data report: water activity of the deep coal-bearing basin off Shimokita from IODP Expedition $337^{1}$
}

\author{
Wataru Tanikawa, ${ }^{2,3}$ Yoko Ohtomo, ${ }^{4}$ Glen Snyder, ${ }^{5}$ Yuki Morono, ${ }^{2,}{ }^{3}$ Yu'suke Kubo, $^{6}$ Yoshihiro lijima, ${ }^{7}$ \\ Takuroh Noguchi, ${ }^{8}$ Kai-Uwe Hinrichs, ${ }^{9}$ and Fumio Inagaki ${ }^{2}, 3,10$
}

\section{Chapter contents}

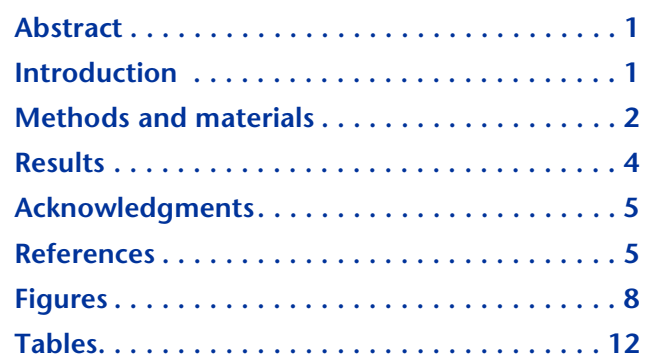

${ }^{1}$ Tanikawa, W., Ohtomo, Y., Snyder, G., Morono, Y., Kubo, Y., lijima, Y., Noguchi, T., Hinrichs, K.-U., and Inagaki, F., 2018. Data report: water activity of the deep coal-bearing basin off Shimokita from IODP Expedition 337. In Inagaki, F., Hinrichs, K.-U., Kubo, Y., and the Expedition 337 Scientists, Proceedings of the Integrated Ocean Drilling Program, 337: Tokyo (Integrated Ocean Drilling Program Management International, Inc.). doi:10.2204/iodp.proc.337.204.2018 ${ }^{2}$ Kochi Institute for Core Sample Research, JAMSTEC, Japan. Correspondence author: tanikawa@jamstec.go.jp

${ }^{3}$ Research and Development Center for Submarine Resources, JAMSTEC, Japan.

${ }^{4}$ Faculty of Engineering, Hokkaido University, Japan.

${ }^{5}$ Gas Hydrate Research Laboratory, Meiji University, Japan.

${ }^{6}$ Center for Deep Earth Exploration, JAMSTEC, Japan.

${ }^{7}$ Graduate School of Bioresources, Mie University, Japan.

${ }^{8}$ Interdisciplinary Science Unit, Research and Education Faculty, Kochi University, Japan.

${ }^{9}$ Center for Marine Environmental Sciences, University of Bremen, Germany.

${ }^{10}$ Research and Development Center for Ocean Drilling Science, JAMSTEC, Japan.

\section{Abstract}

Water activity $\left(A_{\mathrm{w}}\right)$ is one of the physicochemical properties that may influence microbial activity in deep subseafloor environments; however, $A_{\mathrm{w}}$ for subseafloor sediments has never been examined, even at shallow depths. This study investigated $A_{\mathrm{w}}$ data obtained from core samples collected during Integrated Ocean Drilling Program Expedition 337 in the deep-water coal-bearing basin off Shimokita, Japan. $A_{\mathrm{w}}$ did not show any depth dependence and was relatively low in coal-bearing layers. $A_{\mathrm{w}}$ at depths of 0-2466 meters below seafloor ranged from 0.95 to 0.98 , which is quite high and well suited to sustaining microorganisms. $A_{\mathrm{w}}$ for sedimentary rocks was less affected by lithology and porosity than it was by the $\mathrm{NaCl}$ concentration and degree of fluid saturation. In addition, the $A_{\mathrm{w}}$ measurements performed in this study yielded results that corresponded closely with values estimated using Raoult's law and interstitial water chemistry. It therefore appears that $A_{\mathrm{w}}$ for deep-marine sediments is strongly affected by pore water chemistry. The low $A_{\mathrm{w}}$ anomaly in the coalbed unit is considered to be due to contamination by drilling mud and fluid into core samples.

\section{Introduction}

Water activity $\left(A_{\mathrm{w}}\right)$ is an important factor that limits and affects microbial growth in foods and soils; as such, the effect of $A_{\mathrm{w}}$ on bacterial growth has been investigated extensively in the food industry and in soil and plant ecosystems (Stark and Firestone, 1995; Fontana and Campbell, 2007; Welti-Chanes et al., 2007), as well as in habitability assessments of extraterrestrial environments (Tosca et al., 2008). $A_{\mathrm{w}}$ is a measure of how efficiently pore water facilitates the biogeochemical reactions that support microbial growth in solid-fluid systems. Specifically, $A_{\mathrm{w}}$ is defined as the ratio of the vapor pressure of a core sample $(p)$ to that of pure water $\left(p_{0}\right)$ and is expressed as follows (e.g., Grant, 2004):

$$
A_{\mathrm{w}}=p / p_{0}=\mathrm{RH} / 100,
$$

where $\mathrm{RH}(\%)$ is the relative humidity of air and $A_{\mathrm{w}}$ ranges from 0 (no water) to 1 (pure water). A high $A_{\mathrm{w}}$ implies that an environment is more habitable to microbes; most microbes cannot proliferate at water activity values below 0.9 , and even extremophiles, 
such as xerophilic fungi, cannot survive at water activities activity values of $\sim 0.6$ (Grant, 2004; Williams and Hallsworth, 2009; Stevenson et al., 2015).

In the last two decades, scientific ocean drilling programs have discovered microbial communities in deep subseafloor sediments (Parkes et al., 1994; Lipp et al., 2008; Kallmeyer et al., 2012). The number of microbial cells in these deep ocean floor sediments typically decreases with depth, and the microbial populations and the limit of microbial life are probably limited by a combination of chemical, physical, and geological conditions, such as temperature, pore water chemistry, and $\mathrm{pH}$, which also limit microbial survival in soil and food (Sutherland et al., 1994; Jenkins et al., 2002; Hinrichs and Inagaki, 2012); however, the effect of $A_{w}$ on microorganism growth in deep subseafloor sediments remains unclarified. $A_{\mathrm{w}}$ also influences the rate of chemical reactions (Bell and Hageman, 1994; Vittadini and Chinachoti, 2003), which implies that it could be used as an index for mass transport in deep subseafloor environments. Although the physicochemical properties of subseafloor sediments are measured routinely on scientific ocean drilling surveys, the $A_{\mathrm{w}}$ characteristics of subseafloor sediments have never been examined, even at shallow depths. Most pores of subseabed sediments are filled with seawater, and high $A_{\mathrm{w}}$ close to 1 can be expected. However, $A_{\mathrm{w}}$ depends on solute concentration, composition, and temperature (Starzak and Mathlouthi, 2006). Pore size distribution and the fraction of clay minerals that adsorbed water (Beckett and Augarde, 2013) may also influence $A_{\mathrm{w}}$. Therefore, $A_{\mathrm{w}}$ is likely to be lower than expected. The relationship between $A_{\mathrm{w}}$ and the sediment water content, which is referred to as the soil-water characteristic curve (SWCC), is not only useful for estimating unsaturated sediment behavior, but also the pore structure and size distribution, both of which affect permeability (Fredlund and Xing, 1994; Aung et al., 2001).

In this paper, we report $A_{\mathrm{w}}$ measurements conducted on core samples collected from Integrated Ocean Drilling Program (IODP) Expedition 337 (see the "Site C0020" chapter [Expedition 337 Scientists, 2013b]). The effect of lithology, porosity, pore water chemistry, and water content on $A_{\mathrm{w}}$ for core sediments was examined.

\section{Methods and materials}

The deep-water coal-bearing basin off Shimokita lies in the Sanriku Province in a fore-arc basin formed by the subduction of the Pacific plate beneath the
North American plate along the Japan Trench (Fig. F1A). Scientific ocean drilling was performed in the basin off Shimokita during Expeditions 902 (D/V Chikyu shakedown Cruise CK06-06; Aoike, 2007) and 337 (see the "Site C0020" chapter [Expedition 337 Scientists, 2013b]), in order to clarify the main factors responsible for the vertical distribution and limits of microbial activity in the deep sedimentary biosphere. Expedition 902 recovered core samples from 0 to 365 meters below seafloor (mbsf) at Site C9001 $\left(41^{\circ} 10.5983^{\prime} \mathrm{N}, 142^{\circ} 12.0328^{\prime} \mathrm{E} ; 1180 \mathrm{~m}\right.$ water depth), and Expedition 337 drilled deeper at the same location (the site name changed from Site C9001 to Site C0020) to extend the coring depth of Expedition 902. During Expedition 337, core samples were collected from 1276.5 to 2466 mbsf (Fig. F1B).

Sampling for analysis was conducted onshore at the Kochi Core Center, Japan (http://www.kochicore.jp/en/index.html), where the core samples had been stored as half-cylinders measuring 1-1.5 m in length for $7 \mathrm{y}$ (Expedition 902) and $\sim 1$ y (Expedition 337) at $4^{\circ} \mathrm{C}$ in gas-tight bags (ESCAL) to prevent the evaporation of pore fluids from core sediments during transfer and storage (Aoike, 2007; see the "Methods" chapter [Expedition 337 Scientists, 2013a]). Samples for analysis were obtained by subsampling core samples collected at intervals of approximately $40 \mathrm{~m}$ during Expedition 902. For Expedition 337, two samples were collected from every core unit (one unit is approximately $9.5 \mathrm{~m}$ long). Discrete core samples were obtained from working halves. Core samples were sliced into $90^{\circ}$ sectors measuring $<5 \mathrm{~mm}$ in thickness (bulk weight $=4-11$ g) at room temperature $\left(20^{\circ}-25^{\circ} \mathrm{C}\right)$. Each sample was stored in a zipper storage bag after slicing to prevent the evaporation of pore fluid. All $A_{\mathrm{w}}$ measurements were completed one month after the samples were sliced.

\section{$A_{\mathrm{w}}$ measurements}

The water activities of core samples were measured using two commercially available $A_{\mathrm{w}}$ sensors that employed different measurement principles. One method is based on humidity measurements performed using an electric resistance humidity sensor (LabTouch-AW, Novasina, Switzerland), and the other method is based on measuring the dew point using an advanced chilled miller sensor (WP4-T, Decagon Devices, Inc., Pullman, WA, USA). The samples in the zipper storage bags were placed in the laboratory with a room temperature controlled at around $23^{\circ} \mathrm{C}$ before the $A_{\mathrm{w}}$ measurements. Thinsliced samples were retrieved from the bags and put in a disposable plastic cup (40 $\mathrm{mm}$ in diameter and 
$12 \mathrm{~mm}$ deep). Then, a sample was placed in a sealed measurement chamber that allows heating but not cooling to stabilize the temperature of the samples. $A_{\mathrm{w}}$ measurements were initially conducted by the WP4-T system, then we proceeded to measure by using the LabTouch-AW system. The sample temperature, which was controlled using both sensors, was kept at $25^{\circ} \mathrm{C}$ for all measurements. Both sample chambers do not apply confining pressure and pore pressure to samples. Therefore, the $A_{\mathrm{w}}$ measured in this study reflects the value under control conditions and not the in situ value (i.e., Brown et al., 2017).

Based on the product specifications, the WP4-T system was more accurate $( \pm 0.0004)$ than the LabTouch-AW system $( \pm 0.005)$ for higher $A_{\mathrm{w}}$ values $(>0.964)$, with the standard deviation of five replicate $A_{\mathrm{w}}$ readings for 24 samples measured with the WP4-T ( \pm 0.00067$)$ being less than that obtained with the LabTouch-AW ( \pm 0.00089$)$. Temperature control was more accurate with the LabTouch-AW (constant at $\left.25.0^{\circ} \mathrm{C}\right)$ than with the WP4-T $\left(24.9^{\circ}-25.1^{\circ} \mathrm{C}\right)$. The differences in $A_{\mathrm{w}}$ values between the two systems were small for higher $A_{\mathrm{w}}$ values (>0.96), with the $A_{\mathrm{w}}$ values from the WP4-T being smaller than those from LabTouch-AW (<0.96; see Fig. F2; Table T1). We therefore used the $A_{\mathrm{w}}$ measurements obtained using the WP4-T system in this study.

\section{Dependence of $A_{\mathrm{w}}$ on salinity and water content}

The chemical composition, concentration, and water content of aqueous solutions are all affected by the thermodynamic properties and $A_{\mathrm{w}}$ (or vapor pressure) (Fredlund and Xing, 1994; Aung et al., 2001; Starzak and Mathlouthi, 2006). We therefore selected six core samples to investigate the effect of salinity and water content on $A_{\mathrm{w}}$. To measure the effect of the $\mathrm{NaCl}$ concentration on $A_{\mathrm{w}}$, pore water was desalinated and replaced with pure water (Elix, Merck Millipore Corporation, Germany) by immersing core samples in $1 \mathrm{~L}$ of pure water for several days. The pure water was replaced 3 times to ensure that the core sediments were desalinized. The samples were then fully saturated by pure water (Elix) again using a vacuum pump for 1 day before the start of the experiment. After performing the $A_{\mathrm{w}}$ measurements, the $\mathrm{NaCl}$ concentrations of pore water from the same sample were restored by resaturating the core sample in increasing concentrations of $\mathrm{NaCl}$ solution in a stepwise manner. In this way, the same sediment materials were reused to investigate the effect of water content on $A_{\mathrm{w}}$ and to conduct the porosity measurements. To measure the dependence of $A_{\mathrm{w}}$ on pore water content, the water content of the same sample was reduced in a stepwise manner by heating the sample at temperatures between $50^{\circ}$ and $70^{\circ} \mathrm{C}$ using a moisture analyzer (MX-50, A\&D Co., Ltd., Japan).

\section{Computation of $A_{\mathrm{w}}$ values from pore water chemistry}

$A_{\mathrm{w}}$ is generally influenced by the physicochemical characteristics of the interstitial pore water. According to Raoult's law (Taoukis and Richardson, 2007), $A_{\mathrm{w}}$ for an ideal solution is a function of the mole fraction of the dissolved component, and is defined as follows:

$$
A_{\mathrm{w}}=n_{\mathrm{w}} /\left(n_{\mathrm{w}}+n_{\mathrm{s}}\right),
$$

where $n_{\mathrm{w}}$ and $n_{\mathrm{s}}$ are the total moles of water and solutes, respectively. In this study, the interstitial water chemistry data measured on the ship using wholeround core samples, cuttings, and drilling mud during Expeditions 902 and 337 (Aoike, 2007; see the "Site C0020" chapter [Expedition 337 Scientists, 2013b]) was used in Equation 2 to predict $A_{\mathrm{w}}$ for core samples. However, since there was a disparity in the depth between interstitial water data measured on board and the $A_{\mathrm{w}}$ values measured in this study, pore water chemistry analyses were newly performed on core samples from Expedition 902 and on drilling mud fluid from Expedition 337. Samples for water chemistry analyses during Expedition 902 were obtained from core samples from working halves stored for $7 \mathrm{y}$. We selected the massive core samples that did not form fractures and tiny cracks for sampling. The exterior (15-20 mm width) of the half-round section was carefully removed to reduce drilling fluid contamination, and then interstitial water was squeezed from peeled sediment. The drilling fluid was collected from the mud tanks at intervals of approximately $50 \mathrm{~m}$ during Expedition 337 (see the "Methods" chapter [Expedition 337 Scientists, 2013a]), and then stored in plastic bottles $\left(50-100 \mathrm{~cm}^{3}\right)$ at $4^{\circ} \mathrm{C}$ in the Kochi Core Center. Therefore, we used these drilling mud samples (gravimetric water content ranges from 0.75 to 0.92 ). The methodology used for the water chemistry analysis performed in this study was the same as that performed on the ship (see the "Site C0020" chapter [Expedition 337 Scientists, 2013b]). The $A_{\mathrm{w}}$ for pore fluid with a multicomponent of solutes in the core samples was calculated using Geochemist's Workbench (GWB) (Bethke, 2008) and PHREEQC for Windows (version 2.11; Parkhurst and Appelo, 1999); the calculations of $A_{\mathrm{w}}$ using GWB and PHREEQC are based on the Debye-Hückel equation (Helgeson, 1969) and Raoult's law, respectively. 


\section{Porosity measurements}

The porosity and pore water content were calculated from the measured pore and matrix volumes using the same samples as that used for the $A_{\mathrm{w}}$ measurements. Pore volume was calculated from wet and dry weights by drying samples in an oven at $105^{\circ} \mathrm{C}$ for $24 \mathrm{~h}$ ), and the matrix volumes of the core sample were measured using a commercial helium gas pycnometer (Pentapycnometer, Quantachrome Instruments, Boynton Beach, FL, USA). Wet weights were measured just before the $A_{\mathrm{w}}$ measurement, and dry weight measurements were conducted after the $A_{\mathrm{w}}$ measurements. The matrix volume was measured using four replicates, and the average value was used for the porosity calculations. The standard deviation of the matrix volume was $\pm 0.023 \mathrm{~cm}^{3}$, which is equivalent to $\pm 1.5 \%$ and $\pm 0.9 \%$ of the standard errors for the matrix volume and porosity, respectively. In this procedure, we may overestimate porosity, as drying samples at $105^{\circ} \mathrm{C}$ may result in the loss of some interlayer water in clay minerals.

\section{Results}

\section{Depth profile of physical properties}

The $A_{\mathrm{w}}$ for the core samples from Expedition 902 ranged from 0.975 to 0.981 and did not show a clear correlation with depth (Fig. F3A; Table T1). The $A_{\mathrm{w}}$ values from Expedition 337 were highly variable below 1276 mbsf, ranging from 0.954 to 0.983 , whereas the $A_{\mathrm{w}}$ values for samples collected from deeper horizons appeared to be lower than those from shallower depths. Compared to the sequences above and between the coalbed layers, $A_{\mathrm{w}}$ values were relatively lower in coalbed layers. Lower $A_{\mathrm{w}}$ values were also observed at around 1300 mbsf (upper portion of Unit II, near the starting depth of coring in Expedition 337). The $A_{\mathrm{w}}$ values in coal samples, which ranged from 0.977 to 0.979 , were higher than those in the sandstone and siltstone within coalbed layers; however, on the whole, no obvious relationship was observed between $A_{\mathrm{w}}$ and lithology (Table T2).

The porosity of the core samples used in $A_{\mathrm{w}}$ measurement decreased with depth, from 0.81 on the seafloor to 0.2 at the bottom of the core hole (Fig. F3B). The porosity reduction curve is well described by an exponential curve. A very low porosity of $<0.05$ was observed in several depth intervals, and these were considered to represent carbonate-cemented sandstone and siltstone. The logging porosity values calculated using gamma ray bulk density data from the Three-Detector Lithology Density logging tool (see the "Methods" chapter [Expedition 337 Scientists, 2013a]) were relatively lower than core sample porosity values, though the overall agreement between both porosity series was quite similar. Higher porosity zones were observed at around 1950 and 2450 mbsf, where partial coalbed layers were formed, corroborating previously reported porosity-depth trends (Tanikawa et al., 2016).

\section{Effect of physical and chemical properties on $A_{\mathrm{w}}$}

Figure F4A (Tables T3, T4) shows $A_{\mathrm{w}}$ as a function of the weight fraction of $\mathrm{NaCl}$ solution saturated in the core samples. The result shows that the $A_{\mathrm{w}}$ for all samples decreased with increasing $\mathrm{NaCl}$ concentration and that the difference in $A_{\mathrm{w}}$ among the samples was relatively small between replicates at the same concentration. Moreover, the water activities of the sediments were similar, although somewhat lower, than those calculated using Raoult's law for aqueous solutions of $\mathrm{NaCl}$ and the empirical equations introduced by Chirife and Resnik (1984). At higher salinities (>15\%), the empirical curve of Chirife and Resnik (1984) fits the $A_{\mathrm{w}}$ values obtained for the core samples considerably better than Raoult's law. Raoult's law is generally applied to dilute aqueous solutions and is very accurate for $A_{\mathrm{w}}$ values $>0.95$, although marked deviations from the law were observed in more concentrated solutions. The discrepancy between the modeled and measured $A_{\mathrm{w}}$ values can be explained by intermolecular forces and solvation effects in a solution (Fontán and Chirife, 1981; Lilley and Sutton, 1991). The discrepancy at lower salinities $(<5 \%)$ can be explained by incomplete desalination in our procedures.

Volumetric water contents normalized by saturated volumetric water content (degree of water saturation) were plotted against $A_{\mathrm{w}}$ to plot the SWCC (Fig. F4B; Table T5). The water activities for six samples did not decrease at higher water contents, and $A_{\mathrm{w}}$ remained above 0.9 , even after a $10 \%$ reduction in water content (Table T3). $A_{\mathrm{w}}$ in coal samples gradually decreased with decreasing water content at the onset of drying the samples, whereas the water activities for the other four samples were not affected by drying, even when their water contents were reduced by $50 \%$. The sensitivity of $A_{\mathrm{w}}$ to water content can be classified into one of three groups based on the shape of the SWCC, and $A_{\mathrm{w}}$ values for clay at 178 mbsf (Expedition 902 Section 20H-4) and sandstone at 1971 mbsf (Section 337-C0020A-21R-4) showed the lowest sensitivity to water content at higher normalized water contents. This result suggests that the loss of small amounts of pore fluid by drainage or 
evaporation during shipping and sample treatment did not affect the $A_{\mathrm{w}}$ of the samples if one assumes that pore water chemistry did not change.

No significant relationship was observed between $A_{\mathrm{w}}$ and porosity (Fig. F4C). $A_{\mathrm{w}}$ values were highly variable at porosity values below 0.4 and relatively high (0.972-0.974) in samples with very low porosity values (porosity < 0.06). However, as shown in Figure F4C, $A_{\mathrm{w}}$ appears to decrease with porosity when the lower $A_{\mathrm{w}}$ values are selected from a similar porosity range.

\section{Predicted $A_{\mathrm{w}}$ from water chemistry}

Figure F5A shows a comparison of the predicted and measured $A_{\mathrm{w}}$ values for core samples and drilling mud water at $25^{\circ} \mathrm{C}$. The predicted $A_{\mathrm{w}}$ values calculated from the pore water chemistry data were plotted against the $A_{\mathrm{w}}$ values obtained at the same depth as the samples used for the analysis of interstitial water chemistry $(<1.5 \mathrm{~m}$ apart). The values obtained from the analysis with GWB were larger than those obtained with PHREEQC, with deviations from the measured values being slightly smaller for PHREEQC than GWB. The lower predicted $A_{\mathrm{w}}$ values $(<0.96)$ were higher than the measured values, although the deviation between the two values was small at higher $A_{\mathrm{w}}$ values. On the whole, the predicted values were moderately consistent with the measured values, implying that $A_{\mathrm{w}}$ for subseafloor sediments is influenced by the interstitial water chemistry and that water chemistry data can be used to predict $A_{\mathrm{w}}$ for sediments.

The $A_{\mathrm{w}}$ depth profile estimated based on the interstitial water chemistry inferred using PHREEQC is shown in Figure F5B. As core samples from Expedition 902 had been stored for $7 \mathrm{y}$ before water chemistry analyses, oxidation and biochemical reactions might occur to change pore water chemistry. Chemical diffusion between the contaminated outer part and the inner part of the core sample is also expected to occur during storage, and it may result in a mixture of pore water and drilling fluid. Therefore, we did not use pore water chemistry data from Expedition 902 newly measured in this study to estimate the $A_{\mathrm{w}}$ depth profile (Fig. F5B). The predicted $A_{\mathrm{w}}$ for shallow sediments above 350 mbsf from Expedition 902 decreased slightly with depth (0.9826 to 0.982), and the predicted $A_{\mathrm{w}}$ was $\sim 0.04$ higher than the values obtained from the core samples. The predicted $A_{\mathrm{w}}$ values for core samples collected from Expedition 337 ranged from 0.959 to 0.984 , which is consistent with the measured $A_{\mathrm{w}}$ values. The predicted $A_{\mathrm{w}}$ values at the top of Unit II (1277-1378 mbsf; Table T1) were lower than those at other depths but were similar to the measured $A_{\mathrm{w}}$ in core samples, cuttings, and drilling mud at the same depths. The $A_{\mathrm{w}}$ values for cuttings were similar to those for mud water, and both measures were lower than the $A_{\mathrm{w}}$ values measured from core samples. No low anomalies were observed in the predicted $A_{\mathrm{w}}$ values from the coal-bearing layers, but drilling mud fluid had relatively low $A_{\mathrm{w}}$ values in the coalbed. Similarities in the $A_{\mathrm{w}}$ values for mud water samples and cuttings could be explained by high levels of contamination with drilling mud fluid in cuttings (Inagaki et al., 2015), as higher $\mathrm{Cl}^{-}$concentrations in cuttings and drilling mud due to contamination by drilling fluid was reported.

\section{Acknowledgments}

We would like to thank the editor, James Sample, and Sean Toczko for improving the clarity of our manuscript. The present research used core samples and data provided by the Integrated Ocean Drilling Program (IODP) from Expedition 337. We deeply acknowledge the support provided by the staff and laboratory technicians aboard the D/V Chikyu and at the Kochi Institute for Core Sample Research (Japan Agency for Marine-Earth Science and Technology [JAMSTEC]). The present study was supported by the Japan Society for the Promotion of Science (JSPS) Strategic Fund for Strengthening Leading-Edge Research and Development (to JAMSTEC), the JSPS Funding Program for Next Generation World-Leading Researchers (NEXT Program; to Fumio Inagaki), and the JSPS through a Grant-in-Aid for Scientific Research (Number 25800284). We sincerely thank Tomaru Hitoshi for providing the interstitial pore water from Expedition 902.

The data supporting this paper are available at the SIO7 Data Center (http://sio7.jamstec.go.jp).

\section{References}

Aoike, K. (Ed.), 2007. CDEX Laboratory Operation Report: CK06-06 D/V Chikyu shakedown cruise offshore Shimokita: Yokohama (CDEX-JAMSTEC).

Aung, K.K., Rahardjo, H., Leong, E.C., and Toll, D.G., 2001. Relationship between porosimetry measurement and soil-water characteristic curve for an unsaturated residual soil. Geotechnical \& Geological Engineering, 19(34):401-416.

https://doi.org/10.1023/A:1013125600962

Beckett, C.T.S., and Augarde, C.E., 2013. Prediction of soil water retention properties using pore-size distribution and porosity. Canadian Geotechnical Journal, 50(4):435450. https://doi.org/10.1139/cgj-2012-0320 
Bell, L.N., and Hageman, M.J., 1994. Differentiating between the effects of water activity and glass transition dependent mobility on a solid state chemical reaction: aspartame degradation. Journal of Agricultural and Food Chemistry, 42(11):2398-2401. https://doi.org/10.1021/jf00047a007

Bethke, C.M., 2008. Geochemical and Biogeochemical Reaction Modeling: New York (Cambridge University Press).

Brown, K.M., Poeppe, D., Josh, M., Sample, J., Even, E., Saffer, D., Tobin, H., Hirose, T., Kulongoski, J.T., Toczko, S., Maeda, L., and the IODP Expedition 348 Shipboard Party, 2017. The action of water films at $\AA$-scales in the Earth: implications for the Nankai subduction system. Earth and Planetary Science Letters, 463:266-276. https://doi.org/10.1016/j.epsl.2016.12.042

Chirife, J., and Resnik, S.L., 1984. Unsaturated solutions of sodium chloride as reference sources of water activity at various temperatures. Journal of Food Science, 49(6):1486-1488. https://doi.org/10.1111/j.1365-2621.1984.tb12827.x

Expedition 337 Scientists, 2013a. Methods. In Inagaki, F., Hinrichs, K.-U., Kubo, Y., and the Expedition 337 Scientists, Proceedings of the Integrated Ocean Drilling Program, 337: Tokyo (Integrated Ocean Drilling Program Management International, Inc.).

http://dx.doi.org/10.2204/iodp.proc.337.102.2013

Expedition 337 Scientists, 2013b. Site C0020. In Inagaki, F., Hinrichs, K.-U., Kubo, Y., and the Expedition 337 Scientists, Proceedings of the Integrated Ocean Drilling Program, 337: Tokyo (Integrated Ocean Drilling Program Management International, Inc.).

http://doi.org/10.2204/iodp.proc.337.103.2013

Fontán, C.F., and Chirife, J., 1981. Technical note: a refinement of Ross's equation for predicting the water activity of non-electrolyte mixtures. International Journal of Food Science \& Technology, 16(2):219-221. https://doi.org/ 10.1111/j.1365-2621.1981.tb01011.x

Fontana, A.J., Jr., and Campbell, G.S., 2007. Applications of water activity in nonfood systems. In Barbosa-Cánovas, G.V., Fontana, A.J., Jr., Schmidt, S.J., and Labuza, T.P. (Eds.), Water Activity in Foods: Fundamentals and Applications: Hoboken, NJ (Blackwell Publishing Ltd.), 359-372.

https://doi.org/10.1002/9780470376454.ch14

Fredlund, D.G., and Xing, A., 1994. Equations for the soilwater characteristic curve. Canadian Geotechnical Journal, 31(4):521-532. https://doi.org/10.1139/t94-061

Grant, W.D., 2004. Life at low water activity. Philosophical Transactions of the Royal Society, B: Biological Sciences, 359(1448):1249-1267.

https://doi.org/10.1098/rstb.2004.1502

Helgeson, H.C., 1969. Thermodynamics of hydrothermal systems at elevated temperatures and pressures. American Journal of Science, 267(7):729-804. https://doi.org/10.2475/ajs.267.7.729

Hinrichs, K.-U., and Inagaki, F., 2012. Downsizing the deep biosphere. Science, 338(6104):204-205.

https://doi.org/10.1126/science.1229296

Inagaki, F., Hinrichs, K.-U., Kubo, Y., Bowles, M.W., Heuer, V.B., Long, W.-L., Hoshino, T., Ijiri, A., Imachi, H., Ito,
M., Kaneko, M., Lever, M.A., Lin, Y.-S., Methé, B.A., Morita, S., Morono, Y., Tanikawa, W., Bihan, M., Bowden, S.A., Elvert, M., Glombitza, C., Gross, D., Harrington, G.J., Hori, T., Li, K., Limmer, D., Liu, C.-H., Murayama, M., Ohkouchi, N., Ono, S., Park, Y.-S., Phillips, S.C., Prieto-Mollar, X., Purkey, M., Riedinger, N., Sanada, Y., Sauvage, J., Snyder, G., Susilawati, R., Takano, Y., Tasumi, E., Terada, T., Tomaru, H., Trembath-Reichert, E., Wang, D.T., and Yamada, Y., 2015. Exploring deep microbial life in coal-bearing sediment down to $\sim 2.5 \mathrm{~km}$ below the ocean floor. Science, 349(6246):420-424.

https://doi.org/10.1126/science.aaa6882

Jenkins, M.B., Bowman, D.D., Fogarty, E.A., and Ghiorse, W.C., 2002. Cryptosporidium parvum oocyst inactivation in three soil types at various temperatures and water potentials. Soil Biology and Biochemistry, 34(8):11011109.

https://doi.org/10.1016/S0038-0717(02)00046-9

Kallmeyer, J., Pockalny, R., Adhikari, R.R., Smith, D.C., and D'Hondt, S., 2012. Global distribution of microbial abundance and biomass in subseafloor sediment. Proceedings of the National Academy of Sciences of the United States of America, 109(40):16213-16216.

https://doi.org/10.1073/pnas.1203849109

Lilley, T.H., and Sutton, R.L., 1991. The prediction of water activities in multicomponent systems. In Levine, H., and Slade, L. (Eds.), Advances in Experimental Medicine and Biology (Volume 302): Water Relationships in Foods: Boston (Springer), 291-304.

https://doi.org/10.1007/978-1-4899-0664-9_16

Lipp, J.S., Morono, Y., Inagaki, F., and Hinrichs, K.-U., 2008. Significant contribution of Archaea to extant biomass in marine subsurface sediments. Nature, 454(7207):991-994. http://dx.doi.org/10.1038/nature07174

Parkes, R.J., Cragg, B.A., Bale, S.J., Getliff, J.M., Goodman, K., Rochelle, P.A., Fry, J.C., Weightman, A.J., and Harvey, S.M., 1994. Deep bacterial biosphere in Pacific Ocean sediments. Nature, 371(6496):410-413. http://dx.doi.org/10.1038/371410a0

Parkhurst, D.L., and Appelo, C.A.J., 1999. User's guide to PHREEQC (version 2)—a computer program for speciation, batch-reaction, one-dimensional transport and inverse geochemical calculations. USGS Water-Resources Investigations Report, 99-4259.

Stark, J.M., and Firestone, M.K., 1995. Mechanisms for soil moisture effects on activity of nitrifying bacteria. Applied and Environmental Microbiology, 61(1):218-221. http://aem.asm.org/content/61/1/218.abstract

Starzak, M., and Mathlouthi, M., 2006. Temperature dependence of water activity in aqueous solutions of sucrose. Food Chemistry, 96(3):346-370.

https://doi.org/10.1016/j.foodchem.2005.02.052

Stevenson, A., Cray, J.A., Williams, J.P., Santos, R., Sahay, R., Neuenkirchen, N., McClure, C.D., Grant, I.R., Houghton, J.D.R., Quinn, J.P., Timson, D.J., Patil, S.V., Singhal, R.S., Antón, J., Dijksterhuis, J., Hocking, A.D., Lievens, B., Rangel, D.E.N., Voytek, M.A., GundeCimerman, N., Oren, A., Timmis, K.N., McGenity, T.J., 
and Hallsworth, J.E., 2015. Is there a common wateractivity limit for the three domains of life? The ISME Journal, 9(6):1333-1351. https://doi.org/10.1038/ismej.2014.219

Sutherland, J.P., Bayliss, A.J., and Roberts, T.A., 1994. Predictive modelling of growth of Staphylococcus aureus: the effects of temperature, $\mathrm{pH}$ and sodium chloride. International Journal of Food Microbiology, 21(3):217-236. https://doi.org/10.1016/0168-1605(94)90029-9

Tanikawa, W., Tadai, O., Morita, S., Lin, W., Yamada, Y., Sanada, Y., Moe, K., Kubo, Y., and Inagaki, F., 2016. Thermal properties and thermal structure in the deepwater coalbed basin off the Shimokita Peninsula, Japan. Marine and Petroleum Geology, 73:445-461. https://doi.org/10.1016/j.marpetgeo.2016.03.006

Taoukis, P.S., and Richardson, M., 2007. Principles of intermediate-moisture foods and related technology. In Barbosa-Cánovas, G.V., Fontana, A.J., Jr., Schmidt, S.J., and Labuza, T.P. (Eds.), Water Activity in Foods: Fundamentals and Applications: Hoboken, NJ (Blackwell Publishing Ltd.), 273-312.

https://doi.org/10.1002/9780470376454.ch11

Tosca, N.J., Knoll, A.H., and McLennan, S.M., 2008. Water activity and the challenge for life on early Mars. Science,
320(5880):1204-1207.

https://doi.org/10.1126/science.1155432

Vittadini, E., and Chinachoti, P., 2003. Effect of physicochemical and molecular mobility parameters on Staphylococcus aureus growth. International Journal of Food Science and Technology, 38(8):841-847.

https://doi.org/10.1046/j.1365-2621.2003.00738.x

Welti-Chanes, J., Pérez, E., Guerrero-Beltrán, J.A., Alzamora, S.M., and Vergara-Balderas, F., 2007. Applications of water activity management in the food industry. In Barbosa-Cánovas, G.V., Fontana, A.J., Jr., Schmidt, S.J., and Labuza, T.P. (Eds.), Water Activity in Foods: Fundamentals and Applications: Hoboken, NJ (Blackwell Publishing Ltd.), 341-357. https://doi.org/10.1002/9780470376454.ch13

Williams, J.P., and Hallsworth, J.E., 2009. Limits of life in hostile environments: no barriers to biosphere function? Environmental Microbiology, 11(12):3292-3308. https://doi.org/10.1111/j.1462-2920.2009.02079.x

Initial receipt: 11 April 2017

Acceptance: 13 November 2017

Publication: 22 March 2018

MS 337-204 
Figure F1. A. Location of Site C0020 off Shimokita. B. Core lithology, biostratigraphy, and lithologic units in Hole C0020A from Expeditions 902 (CK06-06) and 337. Figures show data modified after Aoike (2007), the "Site C0020" chapter (Expedition 337 Scientists, 2013b), and Inagaki et al. (2015).

A

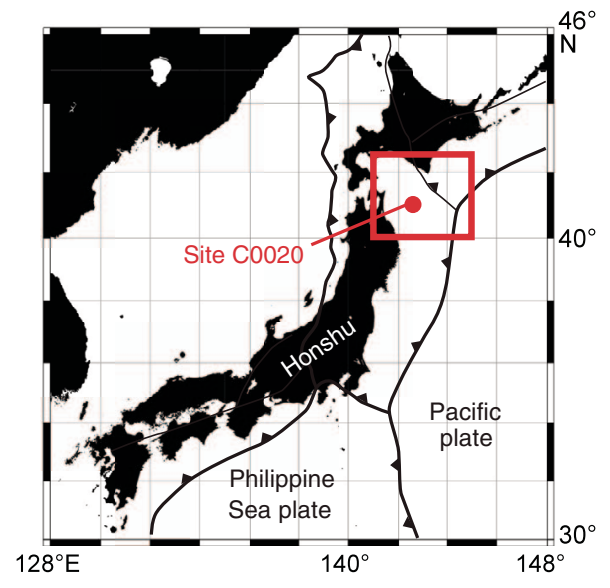

B

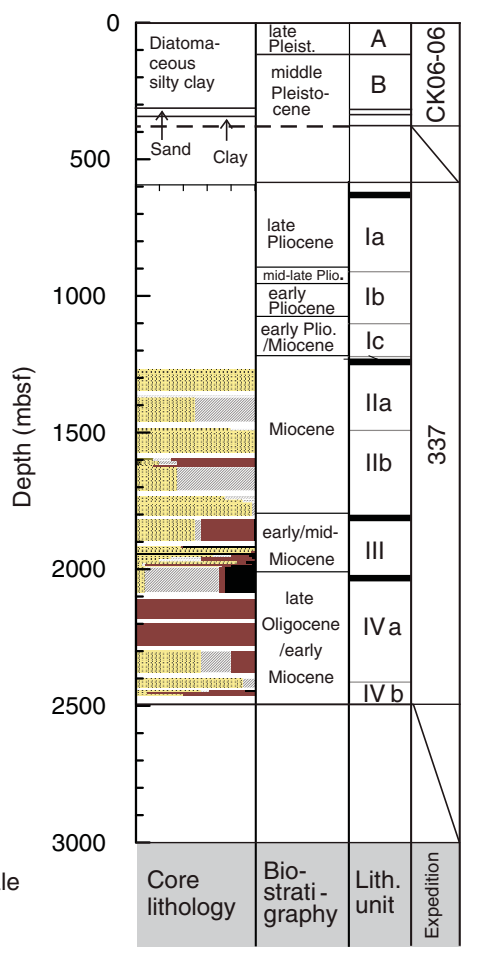

Figure F2. Relationship between water activity measured by WP4-T and LabTouch-AW sensors for the same core samples.

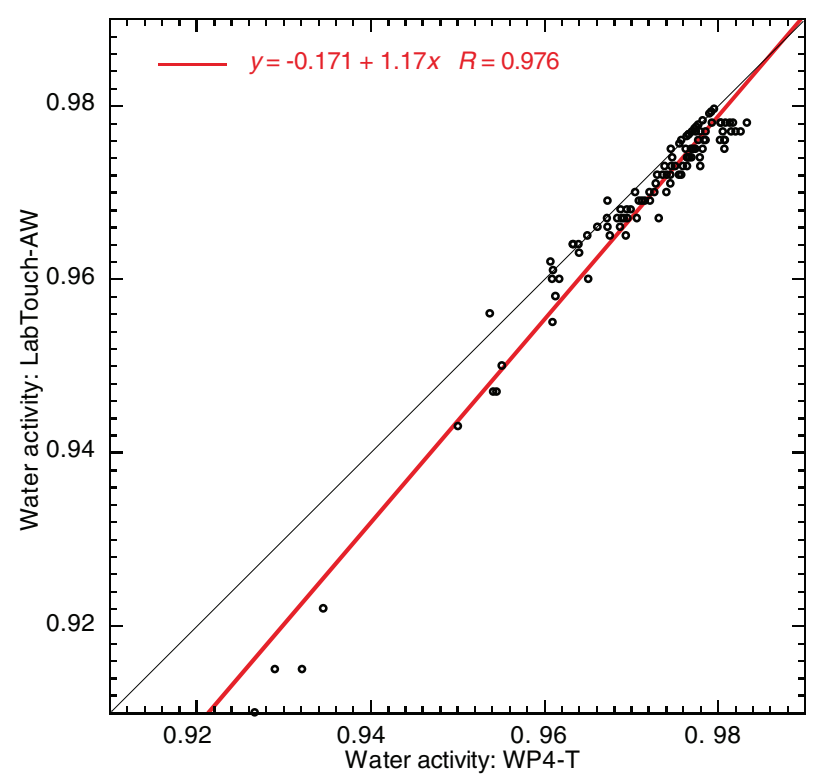


Figure F3. Depth profiles of (A) water activity and (B) porosity of core samples, Hole C0020A.

A

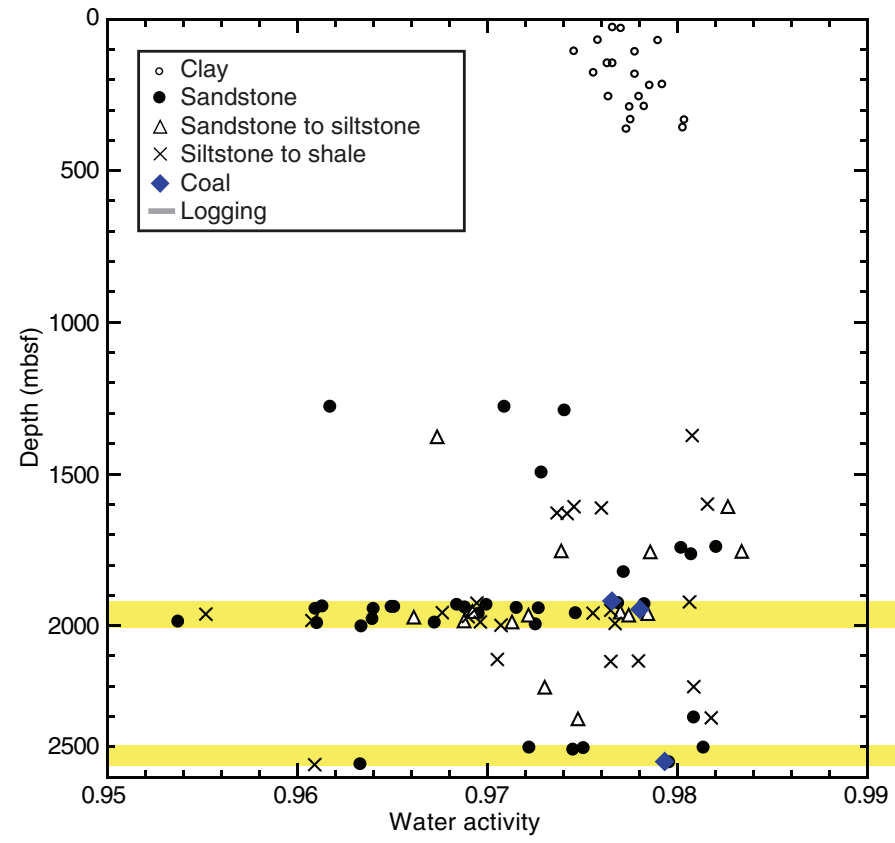

B

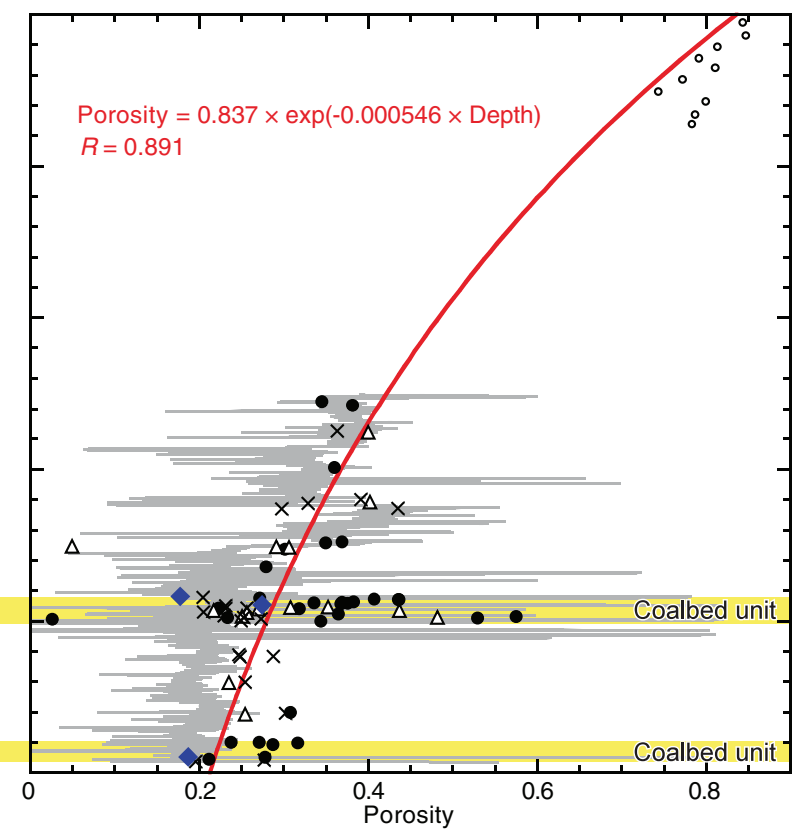


Figure F4. Relationship between water activity and (A) $\mathrm{NaCl}$ concentration, (B) water content normalized using fully saturated water content for core samples (degree of water saturation), and (C) porosity.
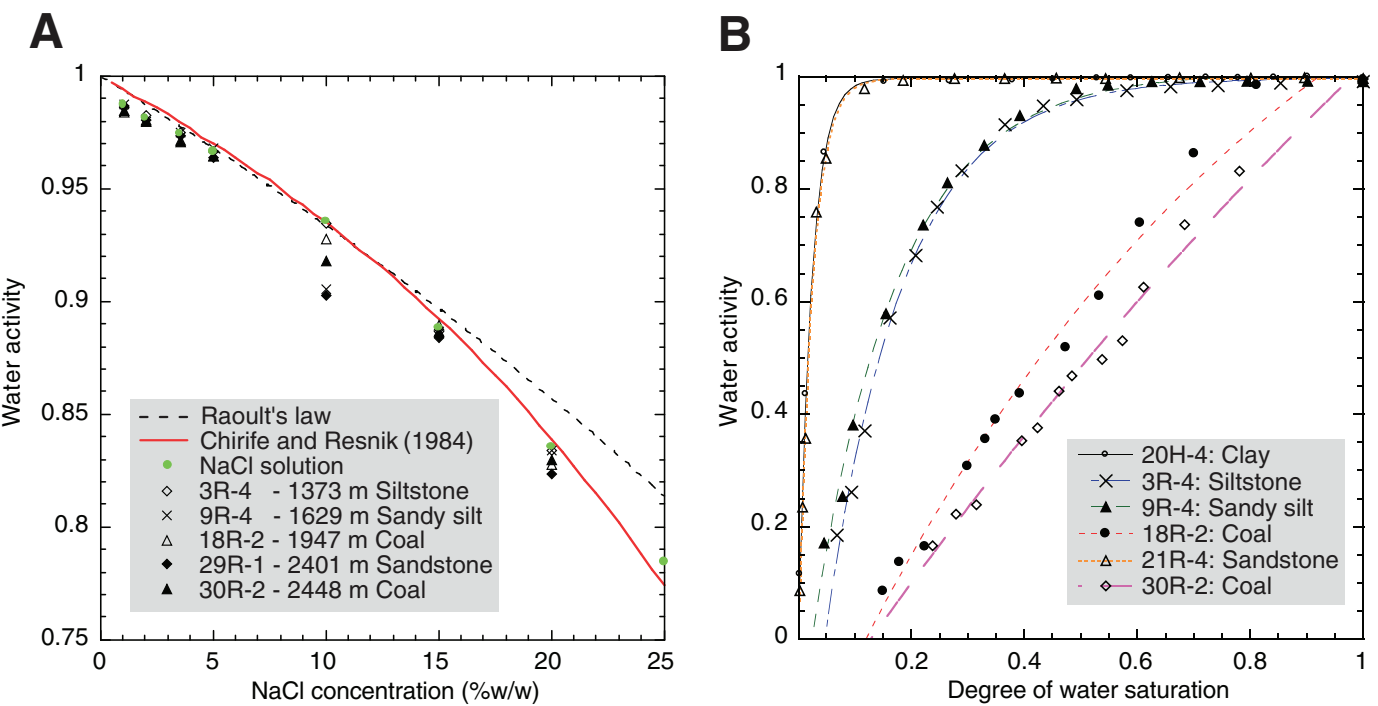

C

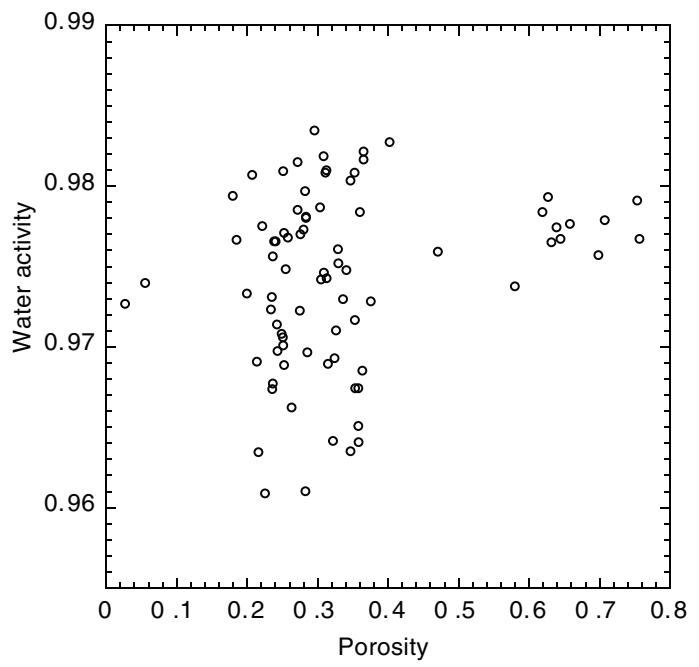


Figure F5. A. Comparison of measured water activity and predicted water activity of core samples. Mean absolute percentage deviations between measured and predicted values are shown on the same figure. B. Depth profiles of predicted water activity at Site C0020. Predicted water activity was calculated from pore water chemistry data measured on the ship (core sample and cuttings) and in this study (drilling mud water). Fluid chemistry data from Expedition 902 newly measured in this study was not used to predict the water chemistry in B.

A

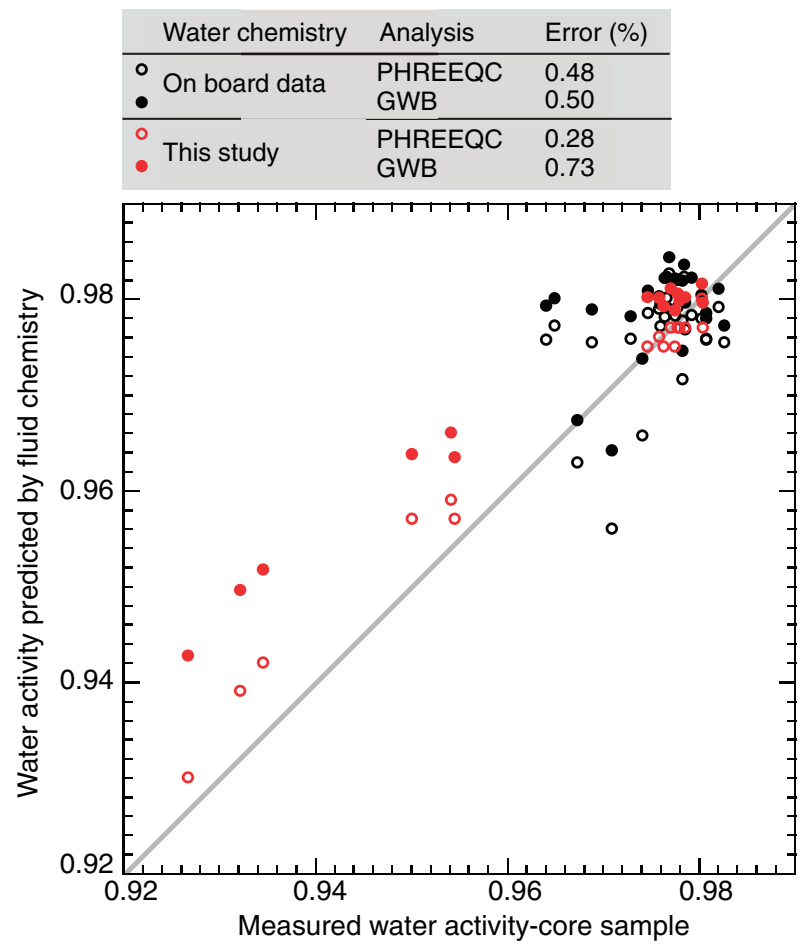

B

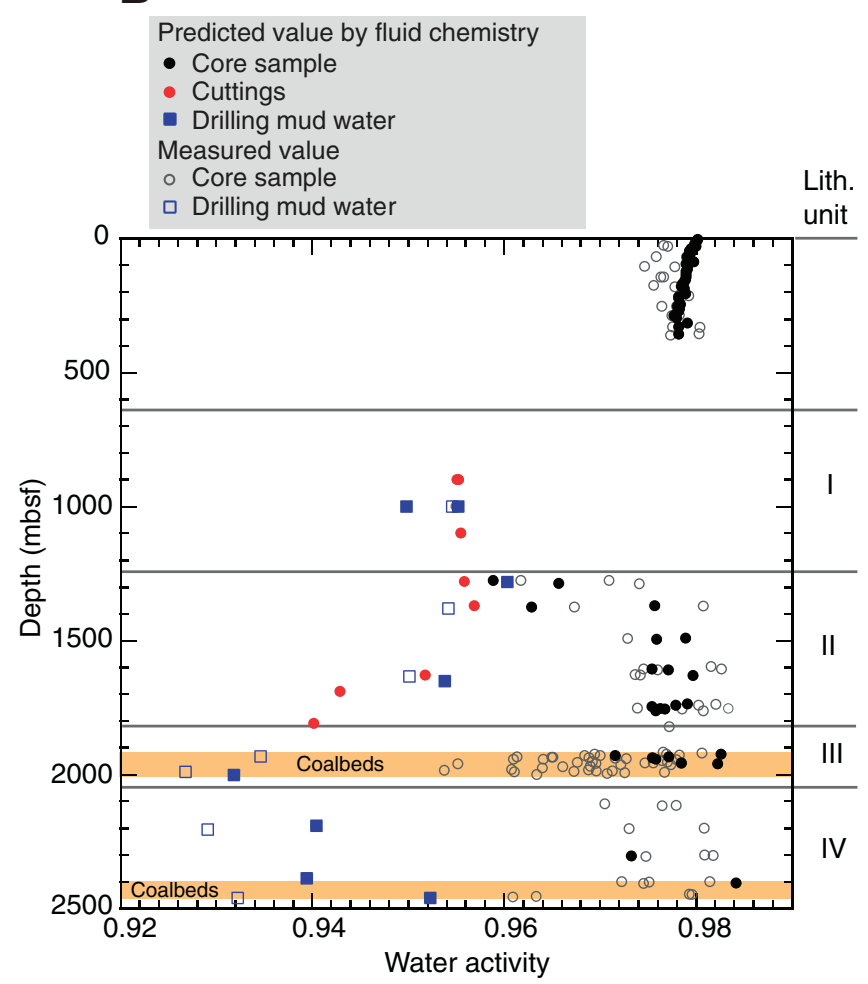


Table T1. Summary of water activity data in core samples collected during Expeditions 902 and 337. This table is available in CSV format.

Table T2. Lithologic variation in water activity $\left(A_{\mathrm{w}}\right)$ and physical properties of core samples, Hole C0020A. This table is available in CSV format.

Table T3. Summary of physical properties of samples used in water activity $\left(A_{\mathrm{w}}\right)$ measurements, Expeditions 902 and 337. This table is available in CSV format.

Table T4. Water activity and $\mathrm{NaCl}$ concentration of pore fluid in core samples collected during Expeditions 902 and 337. This table is available in CSV format.

Table T5. Water activity and degree of water saturation in core samples collected during Expeditions 902 and 337. This table is available in CSV format. 